\title{
Assessing the effect of Waiting Time Management Strategies on Waiting Time Satisfaction among Bank Customers in Ghana
}

\author{
Mbawuni Joseph ${ }^{1}$, \& Nimako Gyasi Simon ${ }^{2}$ \\ ${ }^{1}$ Department of Accounting Studies Education, University of Education, Winneba, Ghana \\ ${ }^{2}$ Department of Management Studies Education, University of Education, Winneba, Ghana \\ Correspondence: Mbawuni Joseph, Department of Accounting Studies Education, University of Education, Winneba \\ Box 1277, KUMASI, Ghana, Canada.
}

Received: November 9, 2017

Accepted: December 4, 2017

Online Published: December 11, 2017

doi:10.5430/afr.v7n1p179

URL: https://doi.org/10.5430/afr.v7n1p179

\begin{abstract}
This paper empirically assesses the effect of waiting time management strategies on consumer waiting time satisfaction (WTS) in bank institutions in an emerging economy, using Ghana banking industry as the research context. Drawing from relevant banking and financial marketing literature, a conceptual framework was developed and tested using empirical data from a cross-sectional survey of 480 sampled customers of commercial banks in Ghana. Data were analysed using partial least squares structural equation modelling (PLS-SEM). The findings indicate that, with the exception of apology for delays, the key factors that influence consumer WTS are perceived compensation, waiting environment, quality of delay information and customer mind-engagement strategies. The findings offer important theoretical and managerial implications to scholars and practitioners in the banking service context. This paper provides an initial study into waiting time management in financial services context in Sub-Saharan Africa.
\end{abstract}

Keywords: Waiting time, Waiting environment, Compensation, Mind-engagement, Delay information, Banking services

\section{Introduction}

Modern banking organisations have shown much interest in customer-centric approaches to banking, which seeks to satisfy and develop long term business relationship with profitable customers (Broberg et al., 2013; Kotler and Armstrong, 2014; Kotler and Keller, 2016). To achieve this, bank managers should not only to be concerned about the accounting information they provide customers in financial statements, but also the effective blend of accounting-marketing relationships that are embedded in the total banking processes for managing customers' account with the bank (Broberg et al., 2013; Collier, 2015; Opute et al., 2016; Saren et al., 2015). In managing relationship with bank customers, one important area of concern to both bank managers and bank customers is customer waiting time. Waiting time refers to the amount of time customers spend waiting to be served completely by a bank (Lerclec, Schmidt, and Dubé, 1995; Lin, Xia, and Bei, 2015; Maister, 1985; Taylor, 1994). As Katz et al. (1991, p. 44) put it:

Customers not only demand quality, they also demand speed. They do not tolerate waiting in line for long periods of time.

The importance of customer waiting time management lies in the fact that customers' perception of waiting time of service providers could affect their current and future relationship with service providers (Lerclec et al., 1995; Lin et al., 2015; Palawatta, 2015). This prception means that when customers are satisfied with the amount of time they wait for services, it can induce loyalty behaviours in customers and influence them to desire more future business with service providers. It is therefore important that service providers do not gloss over customer perceived waiting time (PWT), rather they should develop effective strategies to manage customer PWT in the service delivery process (Lee et al., 2012; Taylor, 1994).

As a result of the importance of customer PWT in financial and non-financial service contexts, there has been considerable research interest from both scholars and practitioners in customer PWT over the last two decades. A review of the extant literature reveals that much of the research in waiting time phenomenon that affect banking institutions has been done in developed economies (e.g., Antonides et al., 2002; Bae and Kim, 2014; Bougoure et al., 
2015; Gohary et al., 2016; Lee et al., 2012; Lerclec et al., 1995; Lin et al., 2015; Maher and Sobh, 2014; McQyuilken, 2017; Nadiri, 2016; Palawatta, 2015). There is very limited empirical research in the area of customer PWT in developing country banking context (e.g., Abbasi et al., 2013). Consequently, this study hopes to contribute to filling this gap in the literate by providing empirical studies that shows the relationship between banks' waiting time management (WTM) strategies and bank customers' waiting time satisfaction (WTS) with such strategies. Therefore, the main purpose of this paper is to examine the impact of organisational waiting time strategies on customer PWT satisfaction in a developing country banking industry context. This study will bring to light empirical findings on, not only the extent to which banks' WTM strategies influence customers' satisfaction, but also the relative effect of each WTM strategy, especially in emerging economy context to advance empirical knowledge on customer PWT in banking industry in developing countries.

The financial market has been growing globally. In Sub-Sahara Africa in general and Ghana in particular, financial market is one of the fastest growing market with many innovative products and services being developed continually (Allen, Otchere, and Senbet, 2011; Mbawuni and Nimako, 2015). These financial products range from banking services such as savings, fixed deposits, current accounts, investment services, insurance services to micro credit and microfinance services as well as other non-banking financial services such as mutual fund, assets management, among others.

One of the reasons for the fast growth of the financial market is the effective marketing communication for promotion of financial products. Consumers and investors in the financial market are always interested to know a great deal of information from different sources to learn about financial institutions and their products, and make purchasing and investment decisions (Xiong and Bharadwaj, 2013; Kotler and Keller, 2012). Financial service providers adopt varieties of marketing communication tools to promote financial products such as advertising, sales promotion, events and experiences, public relations and publicity, direct marketing, interactive marketing, word-of-mouth marketing, and personal selling (Kotler and Keller, 2016). Among these promotional tools advertising is arguably the most widely used promotional tool by financial service institutions.

Advertising plays an important role in delivery of financial news and vital financial product information for consumer purchasing and investment decisions (e.g., Xiong and Bharadwaj, 2013; Latif and Abideen, 2011; Zhang and Skiena 2010). Ineffectiveness of advertising has the potential of inducing negative consumer attitude towards financial products (e.g., El-Adly, 2010; Latif and Abideen, 2011; Waller, 1999). Consumer attitude towards financial adverts is important because negative consumer attitude can lead to advertising avoidance behaviours, low purchasing intentions and low recommendation of product/services (Chowdhury, Finn, and Olsen, 2007; El-Adly, 2010; Teixeira, Michel, and Pieters, 2010). It is important for financial service providers to understand critical factors that affect consumer attitudes towards financial adverts. As a result, there has been growing interest in research into consumer attitude to financial adverts in recent times.

However, while much research has been done in consumer behaviour towards financial adverts in many different service contexts (e.g., Chowdhury et al. 2007; El-Adly, 2010; Teixeira et al., 2010; Waller, 1999; Crain, 2014; Swani, and Iyer, 2015), there is limited research in financial adverts in developing countries and Ghana in particular (Bashiru and Bunyaminu, 2013). Therefore, the main purpose of this study is to examine critical factors that influence consumer attitude towards financial adverts in Ghana banking industry. This study will contribute to the literature by providing empirical evidence on consumer attitude towards financial adverts in a developing country context, and providing management with empirical feedback for developing effective strategies for improving promotion of financial products, especially in the developing countries in general, and Ghanaian financial market in particular. This study is guided by the following objectives:

1. To examine bank customers' participation in financial adverts in Ghana.

2. To determine the extent to which content of financial advert and customer participation in financial adverts influence customer attitude towards financial adverts in Ghana.

\section{Literature Review and Hypothesis}

\subsection{Concept of Customer Waiting Time}

Waiting time basically refers to the average time customers wait for the completion of services they require from a service provider for a given period (Kotler and Keller, 2016; Lin et al., 2015; Taylor, 1994). According to the psychology and marketing literature, the concept of customer waiting time has different dimensions and typologies. First, waiting time could be objective or subjective (Pruyn and Smidts, 1993; Smidts and Pruyn, 1994; Taylor, 1994). Objective or actual waiting time refers to the actual waiting duration the customer has been waiting to be served. 
This could be estimated consciously and objectively by reading the clock to find the time a customer has actually waited to be served by a service provider. Subjective waiting is also called perceived waiting time because it is the time duration that the customer feels he/she has been waiting for the service (Bae and Kim, 2014). This study focuses on perceived waiting time because it has been found as critically important to customers and it can influence customer satisfaction more than actual waiting time in both marketplaces and marketspaces (online) (Lee et al, 2012). According to Maister (1985), PWT can be influenced by many factors such as the waiting stage, customer's value for the service, the consumer level of anxiety, consumer level of certainty of wait time, whether the customer is occupied or not, whether explanation is given for the wait or not, and whether the customer is alone or not.

Waiting process could also be described in three stages as pre-process waits, in-process waits, and post-process waits (Bae and Kim, 2014; Taylor, 1994); A pre-process wait occurs before the customer is seated; an in-process wait occurs during order taking and during the meal; and a post-process wait occurs prior to receiving and paying the cheque (Taylor, 1994). In relation to the banking service context of this study, pre-process waiting occurs before approaching the counter in bank, in-process waiting during transaction execution at the banking hall, and post-process waiting during transaction completion by the staff of the bank or self-service by customer (Bae and Kim, 2014).

Moreover, previous research has identified high-cost wait and low-cost wait situations (Cameron et al., 2003; Bae et al., 2014). High cost wait are situations in which the cost of wait to the customer is too high while low-cost wait are wait situations that are less expensive in times of money or other value to the customer. With regards to a service in an airplane, delay may be an example of a high-cost wait and the waiting lines in a restaurant may be an example of a low-cost wait. This study examines low-cost waits in waiting lines in banking service setting. As a result of competition, waiting time in banking industry is important since it could negatively influence customer satisfaction (Cameron et al., 2003). Finally, there are acceptable and unacceptable waiting times (Hwang and Lambert, 2005). Acceptable waiting time is the waiting time consumers are willing to tolerate as normal for a given service delivery while unacceptable waiting time refers to waiting time considered by a customer as relatively unreasonable to wait for a given service to be completed by a service provider.

\subsection{Waiting time Satisfaction (WTS)}

Waiting time satisfaction generally refers to consumers' evaluation of a given waiting duration as meeting their expectations and desires or not. Previous research has found that customers tend to be relatively dissatisfied with long waiting time compared with short waiting time generally (Taylor, 1994; Lee et al., 2012; Lin et al., 2015). Customers also tend to be dissatisfied with waiting duration for service delivery where they are uncertain about waiting time, when they do nothing during waiting, when they are with a group, when there are no explanations, apology or compensations for perceived unacceptable waiting durations (Bae and Kim, 2014; Antonides et al., 2002; Kumar et al., 1997). Customer satisfaction with waiting time can affect their post-purchase decisions such as repeated patronage, recommendation of service provider and loyalty to service provider (Abbasi et al., 2013; Lerclec et al., 1995; Lin et al., 2015; Palawatta, 2015).

\subsection{Waiting Time Management (WTM) Strategies and Waiting Time Satisfaction (WTS)}

In order to achieve high levels of waiting time satisfaction (WTS), business organisations must develop effective waiting time strategies to deal with customer dissatisfaction with waiting duration. In situations where the actual waiting period cannot be changed, it is critically important for financial service providers to formulate strategies to manage customer PWT in terms of filled time (Taylor, 1994, 1995; Hui et al., 1997), service stage (Houston et al., 1998), uncertain waits (Taylor, 1994; Kumar and Krishnamurthy, 2008), unexplained waits (Hui and Tse, 1996), and fairness (Oberholzer-Gee, 2006; Voorhees et al., 2009). An organisation's waiting management (WTM) strategies are a set of waiting time fillers meant to reduce the consumer's PWT dissatisfaction. A review of the extant banking and marketing literature shows a number of strategies service providers use to manage customers PWT in order to influence customers' WTS. Thus, it is proposed that banking organisation's WTM strategies will have significantly positive effect on bank customers' waiting time satisfaction (WTS). Specifically, the more effective the organisation's WTM strategies, the greater the positive effect on bank customers' WTS for banking services.

\subsection{Conceptual Framework for the Relationship between WTM and WTS}

Based on this proposed theoretical relationship between an organisation's WTM strategies and customers' WTS, and the hypotheses for the study are discussed in the following sub-sections. From Figure 1, this study includes in its conceptual framework five WTM strategies, which are apology for delays, managing waiting environment, improving quality of delay information, providing compensation and developing mind-engagement strategies. The 
five WTM strategies are the independent variables for the study while customers WTS is the only dependent variable.

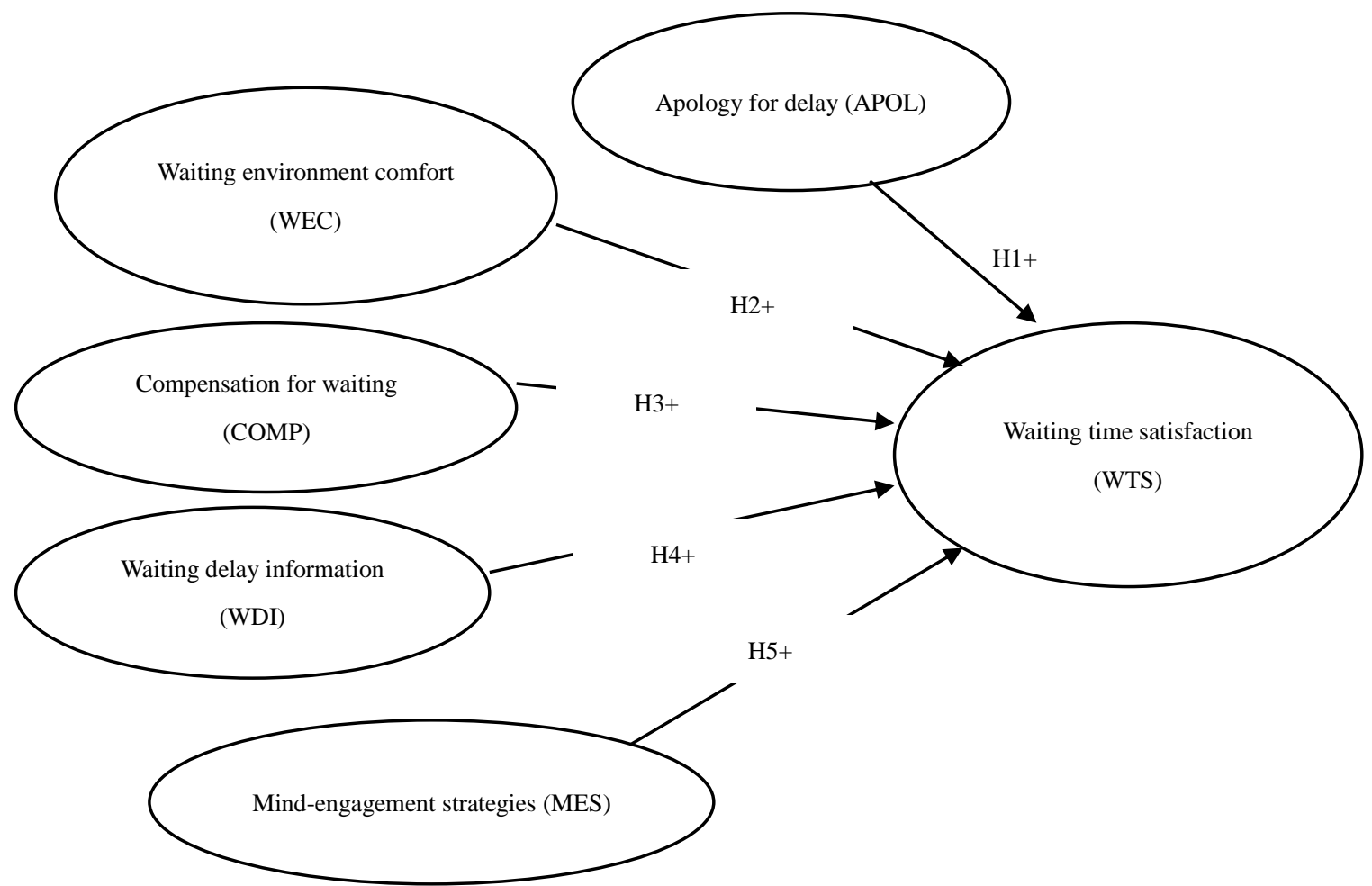

Figure 1 conceptual framework and hypotheses for the study

\subsubsection{Apologies and Waiting Time Satisfaction (WTS)}

Apology refers to a bank's expression of regret for inconveniencing customers or making customers to wait too long for service. Firms may decide to apologise for delays they might have caused customers in the service delivery process. It is well documented that customers tend to welcome polite, sincere and unconditional apology from service providers when things go wrong with service provider's ability to deliver on time (Antonides et al., 2002; Bae and Kim, 2014; Lee et al., 2012; Lin et al., 2015). Where service provider do not apologise to customers, it could be perceived by customers as irresponsibility and lack of care for customers. This could result in customers' dissatisfaction with the service delivery process. An apology is most appropriate when social or process-related service failures occur (Wirtz and Mattila, 2004). Bougoure et al (2015) showed that at a service firm's effective complaint handling positively impacts satisfaction with complaining, overall satisfaction and credibility. They also found that the higher the perceived magnitude of failure, the more difficult it is to satisfy a customer. McQyuilken (2017) found that in a high contact service environment, appropriate apology to customer can lead to their satisfaction. Nadiri (2016) found that perceived justice of customers has a significantly positive effect on their service recovery satisfaction in banking services. Bank's apology for service delays and customer waiting in banking hall could be perceived by customers as a duty the service provider owes them and as a kind of justice treatment they deserve or require from service firms to settle their dissatisfaction with poor service experienced. Tarofder et al (2016) found that apology for service failure, together with excuse, justification, reference, is one of the basic component of a banks explanation on service failure, which could result in higher customer satisfaction if applied effectively. Mostafa et al (2014) developed service recovery scale, the CURE scale, and found apology as one of the strategies for achieving service recovery that has the strongest influence on service recovery satisfaction. Maher and Sobh (2014) also found apology to be an effective strategy to reduce customer complaint about waiting time and increase customer satisfaction.

Thus, there is empirical evidence that rendering appropriate and timely apology to service customers for delay and 
other service failures resulting from long waiting for service provision has been found to be an effective complaint management strategy, which is able to create some level of customer satisfaction with waiting situations in banks (Bougoure et al., 2015; Gohary et al. 2016; Nadiri, 2016; McQyuilken, 2017). Hence, we hypothesise that:

H1: Apology for delays will have significantly positive effect on waiting time satisfaction (WTS) among bank customers. Specifically, the stronger the apology, the stronger will be the customer's WTS.

\subsubsection{Waiting Environment Comfort (WEC) and Waiting Time Satisfaction (WTS)}

Wait environment comfort refers to the extent to which a customer feels comfortable in the waiting environment or banking hall while waiting to be served. Service providers could manage the waiting environment by ensuring that the waiting environment provides customers' comfort while they wait for banking service. McQyuilken (2017) found that in a high contact service environment, wait comfort is obligatory in reducing customer complaint, while wait effort and apology are substitutable when comfortable waits are provided. Many past studies have shown that when customers perceive the waiting environment to be comfortable by looking neat, not congested, welcoming, refreshing, pleasant, attractive with appropriate temperature and seating for relaxation, it could positively contribute to making customers satisfied with waiting periods in banking (Antonides et al., 2002; Bielen et al., 2007; Lee et al., 2012; Lin et al., 2015). This leads to the hypothesis that:

H2: Waiting environment comfort will have significantly positive effect on waiting time satisfaction (WTS) among bank customers. Specifically, the higher the WEC, the higher will be the customer's WTS.

\subsubsection{Quality Delay Information (QDI) and Waiting Time Satisfaction (WTS)}

Quality information on service delay (QDI) refers to service provider's communication of timely and appropriate information about service delay to customers waiting for service, either in the pre-service encounter or service-encounter situations. Service providers could also provide customers with quality information on an unplanned and planned delay for service delivery (Antonides et al., 2002; Lee et al., 2012; Lin et al., 2015). Where service delivery is likely to be delayed as a result of technical operational factors beyond the control of bank service provider, especially within the short-term, there is the need to communicate such delay information to customers well in advance (Bae and Kim, 2014). Such advanced information on likely service delays enables bank customers to make their own adjustment to overcome the effect of the delay in service. It also gives customers an impression that service providers are in control of the service delivery process, strengthening service providers' ability to management the service delivery process and provide assurance and security to customer for service delivery, while enforcing customer confidence in service provider's ability to deliver in service co-creation (Gohary et al., 2016; Jaakkola and Alexander, 2014; Vargo and Lusch, 2014). However, Kumar and Krishnamurthy (2008) found that service-time uncertainty in anticipated congestion has a critically negative impact on customers' waiting-time decisions. Thus, where service providers can provide quality delay information it could lead to waiting time satisfaction in customers. Therefore, we hypothesise that:

H3: Quality of delay information will have significantly positive effect on waiting time satisfaction (WTS) among bank customers. Specifically, the higher the perceived QDI, the higher will be the customer's WTS.

\subsubsection{Compensation for Waiting (CMP) and Waiting Time Satisfaction (WTS)}

Compensation for waiting refers to any form of reward that is given by service provider to waiting customers for patiently waiting for them to be completely served by service providers. While waiting time compensations may vary, one commonly used is waiting time guarantees (Antonides et al., 2002; Hill et al., 2000). Waiting time guarantees are a kind of commitment from a service provider to serve its customers within a specified period of time. If a firm fails to meet this commitment for some customers then it compensates them for the delay (Kumar et al., 1997). Kumar et al., (1997) offered their participants waiting-time guarantees. They found that satisfaction with the wait was relatively positive if the waiting time was shorter than the guaranteed time limit. Waiting time compensation or reward provides a form of value to waiting customer for the time wasted in waiting for service to be completed (Lin et al., 2015). Generally, when customers are compensated for service delays and other service failures, they are more likely to be satisfied than when they are rather made to pay for waiting for service (Antonides et al., 2002). Thus, waiting time compensations tend to have a positive effect on customers' waiting time satisfaction (Kumar et al., 1997; Taylor, 1994). This leads to the hypothesis that:

H4: Compensation for waiting will have significantly positive effect on waiting time satisfaction (WTS) among bank customers. Specifically, the higher the compensation, the higher will be the customer's WTS. 


\subsubsection{Mind-engagement Strategies (MES) and Waiting Time Satisfaction (WTS)}

Mind engagement strategies refer to a group of service providers' strategies and tactics that are meant to engage the mind of customers while they wait for services (Antonides et al., 2002; Bae and Kim, 2014; Katz et al., 1991). These tactics are meant to help customers find something interesting, useful and thoughtful doing while they wait for service. In the literature, Lee et al., (2012) referred to mind-engagement as "filler interfaces" (Lee et al., 2012). In this regard, fillers or MES include firms' provision of music, television and video shows in the waiting environment such as the banking hall for customer to fill the time with something worthwhile as they wait to be served. Other service providers may serve customers water, coffee, candies, and chocolates for customers' consumption, and may provide menu information while they wait for service completion (Bae and Kim, 2014). These MES are not necessarily compensations but a way of shortening the PWT and helping waiting customers to have positive moods and feelings instead of thinking about and being concerned about the issue of having to wait of service (Lee et al., 2012; Tometal, 1997). In particular, Tometal (1997) showed that musical entertainment shortened perceived waiting time in one of their experiments.

Lee et al., (2012) found strong support for the positive effect of mind-engagement fillers on customer online waiting perceptions and web satisfaction experience. Bae and Kim (2014) also found that offering menu information and playing appropriate music in the service environment have positive effect on customer perceived waiting time. Moreover, Lee et al. (2012) found varying differential effect of various fillers such as background music, news and entertainment on customer evaluation of waiting time. Thus, generally, the literature points to the fact that effective use of mind-engagement fillers could have a positive influence on customers' satisfaction of waiting time by shortening customers' perception of the waiting time at the service encounter stage. Hence, we hypothesize that:

H5: Waiting environment comfort will have significantly positive effect on waiting time satisfaction (WTS) among bank customers. Specifically, the higher the WEC, the higher will be the customer's WTS.

\subsection{Ghana's Banking Industry}

In Ghana's banking industry, there are 36 banks and 97 approved micro finance institutions. There is high competition in the industry. All the banks in Ghana are made up of commercial and rural banks, and operate under conventional regulations (BoG, December 2015 https://www.bog.gov.gh). The main GBI regulator is the BoG that supervises and regulates the industry using regulatory instruments such as Bank of Ghana Act, 2002 (Act 612), Banking Act, 2004 (Act 673), Non-Bank Financial Institutions Act, 2008 (Act 774), Companies Code Act 179, 1963, and Bank of Ghana Notices/Directives/ Circulars / Regulations. The GBI is fasting growing and has high potential of attracting local and international banking and financial investors. For, banking institutions, the issues of waiting time management is not entirely a new phenomenon. Many banks make efforts to reduce the negative effect of waiting time on consumer behaviour. However, there is dearth of empirical research in this regard. This has implication for the banking industry in Ghana needs to be abreast with empirical research information regarding the effect of waiting time management on consumer behaviour in order to develop effective strategies to manage it to survive the intense competition in the Ghana banking industry.

\section{Methodology}

This study was a cross-sectional survey that sought to collect field data on bank customers' evaluation of the effect of bank institutions' WTM strategies on their satisfaction with waiting time. The population consisted of bank customers in the Ghana banking industry. A convenient sample size of 600 respondents was chosen for the study. A survey was conducted in the central business district of Kumasi in Ghana in February, 2016.

The main data collection instrument used was a self-administered structured questionnaire (see Appendix A). The questionnaire items were based on many previous studies reviewed but modified to suit the research context (e.g., Antonides et al., 2002; Bae and Kim, 2014; Bougoure et al., 2015; Gohary et al. 2016; Lee et al., 2012; Lin et al., 2015; Maher and Sobh, 2014; McQyuilken, 2017; Nadiri, 2016). It had two sections in all; one section focused on the five organisation's WTM strategies and WTS as indicated in the conceptual framework, and the other sections related to respondent background data such as gender, age, education, income and bank account type. A five-point Likert scale was used to measure variables for the research constructs since previous studies recommend the use of five-point likert scale because it has strong predictive power like seven-point Likert scale (e.g., Danaher and Haddrell, 1996). The Likert scale ranged from strongly disagree to strongly agree, coded 1 to 5 respectively.

In administering the research instrument, the questionnaire was pre-tested and finally administered to the target population. We used an informed consent form to seek permission from the respondents and assured them of anonymity of their identity and confidentiality of their responses. Out of the 600 questionnaire administered, a 480 
usable questionnaire were obtained, representing $80 \%$ response rate. This is considered a high response rate for survey research of this nature (Hair et al., 2010).

\section{Data Analysis and Results}

Data were analysed using descriptive analysis for the respondents' background data and partial least squares structural equation modelling approaches available in SPSS 16.0 and Smart PLS 2.0 (Ringle et al., 2005) respectively.

To test the structural relationships among the constructs in the proposed model, Partial Least Squares Structural Equation Modelling (PLS-SEM) was employed using SmartPLS 2.0 software (Ringle et al., 2005). PLS was chosen because of its distribution-free assumption, the predictive focus, and especially, for the purpose of the explanatory model development approach for understanding the relationship between banking organisations' WTM strategies and customers' WTS as suggested in the literature (Chin, 2010). In determining the sample size for PLS-SEM, the rule of ten was applied as suggested by Hair et al. (2011). This rule suggests that the minimum sample size should be ten times the highest number of structural paths directed at a latent construct at a time (Hair et al., 2011, p. 144). The highest number of structural paths directed at a latent construct (attitude towards IB) at a time in our proposed model was six. Hence six multiplied by ten gives 60 cases for minimum sample size. Thus, our sample of 480 respondents could be described as adequate sample size. For the estimation of significance of t-values, 500 bootstrap resamples were run (Chin, 2010). A two-step SEM approach was followed as suggested for PLS-SEM analysis (Hair et al., 2011, p.144; Chin, 2010): estimation of the measurement (outer) model before fitting the structural (inner) model.

\subsection{Respondents' Profile}

In terms of gender, $38.3 \%$ of the respondents were males and $61.7 \%$ were females. $53.3 \%$ of the respondents were 35 years and below, 29.2\% were between the ages of 36 and 45 while $7 \%$ were 46 years and above. In terms of education, about $13.3 \%$ of them had lower than Diploma/Higher Diploma levels of education, 28.3\% had Diploma level education and about $42.5 \%$ had degree level education, while $15.8 \%$ had post-graduate and master's degree education. About 58\% of the respondents earned a monthly income below USD 500, 30.9\% of them earned monthly income above USD 500, while $10.8 \%$ of them are non-income earner. $65 \%$ of the respondents operated savings accounts, 21.7 operated current or salary accounts, $5 \%$ owned insurance products, $2.5 \%$ of them had taken loans services from their service providers, while $5.8 \%$ of them used fixed deposit, investment accounts and treasury bills.

\subsection{Measurement Model Reliability and Validity}

Construct reliability measures the extent of internal consistency of measures used, and it is assessed through at item factor loadings with acceptable value of 0.50 and through Cronbach's alpha with the acceptable level of 0.7 (Hair et al., 2010; Hair et al., 2011, p.144). From Table 1, all of the constructs have item loadings higher than the recommended 0.50 . 
Table 1. Item loading and cross loadings

\begin{tabular}{lllllll}
\hline & APOL & COMP & WDI & MES & WEC & WTS \\
\hline APOL1 & 0.852 & 0.299 & 0.402 & 0.400 & 0.352 & 0.325 \\
APOL2 & 0.864 & 0.269 & 0.583 & 0.428 & 0.267 & 0.337 \\
COMP1 & 0.207 & 0.890 & 0.256 & 0.605 & 0.190 & 0.463 \\
COMP2 & 0.420 & 0.906 & 0.362 & 0.679 & 0.242 & 0.534 \\
COMP3 & 0.245 & 0.900 & 0.243 & 0.615 & 0.171 & 0.462 \\
WDI1 & 0.550 & 0.291 & 0.895 & 0.404 & 0.324 & 0.404 \\
WDI2 & 0.494 & 0.258 & 0.903 & 0.338 & 0.291 & 0.360 \\
WDI3 & 0.415 & 0.283 & 0.749 & 0.330 & 0.396 & 0.285 \\
WDI2 & 0.348 & 0.376 & 0.234 & 0.672 & 0.244 & 0.214 \\
MES3 & 0.352 & 0.685 & 0.327 & 0.867 & 0.170 & 0.418 \\
MES4 & 0.471 & 0.617 & 0.423 & 0.895 & 0.396 & 0.581 \\
WEC1 & 0.163 & 0.174 & 0.316 & 0.255 & 0.807 & 0.332 \\
WEC2 & 0.329 & 0.166 & 0.325 & 0.278 & 0.828 & 0.428 \\
WEC3 & 0.353 & 0.205 & 0.293 & 0.296 & 0.776 & 0.384 \\
WTS1 & 0.284 & 0.575 & 0.368 & 0.523 & 0.451 & 0.900 \\
WTS2 & 0.337 & 0.460 & 0.357 & 0.462 & 0.449 & 0.913 \\
WTS3 & 0.430 & 0.418 & 0.397 & 0.478 & 0.388 & 0.883 \\
\hline
\end{tabular}

Note: APOL - apology, WEC - Waiting environment comfort, COMP - Compensation for waiting, WDI- Waiting delay information, MES - mind-engagement strategies, WTS - waiting time satisfaction

Table 2. Construct reliability and discriminant validity

\begin{tabular}{clllllllll} 
& APOL & COMP & WDI & MENG & WEN & WTS & AVE & CR & CA \\
\hline APOL & 0.858 & & & & & 0.737 & 0.848 & 0.642 \\
COMP & 0.331 & 0.898 & & & & 0.807 & 0.926 & 0.881 \\
DINF & 0.576 & 0.323 & 0.852 & & & 0.726 & 0.888 & 0.810 \\
MEN & 0.483 & 0.707 & 0.421 & 0.817 & & 0.668 & 0.856 & 0.770 \\
WEN & 0.359 & 0.226 & 0.387 & 0.345 & 0.804 & & 0.646 & 0.846 & 0.728 \\
WTS & 0.385 & 0.544 & 0.416 & 0.544 & 0.479 & 0.899 & 0.807 & 0.926 & 0.881 \\
\hline
\end{tabular}

Notes: square roots of AVEs are in the diagonal; correlations are below the diagonal; AVE-Average variance extracted, CR-

Composite reliability, CA - Cronbach's alpha. APOL-apology, WEC-Waiting environment comfort, COMP-Compensation for waiting, WDI- Waiting delay information, MES - mind-engagement strategies, WTS - waiting time satisfaction

In Table 2, all Cronbach alphas are above 0.70 except one construct, indicating that these multiple measures are highly reliable for the measurement of each construct. Construct validity assesses the degree to which a measurement represents and logically connects the observed phenomenon to the construct through the fundamental theory (Fornell and Larcker, 1981). It is assessed through convergent validity and discriminant validity (Hair et al., 2011).

Convergent validity was considered adequate since the average variance extracted (AVEs) and composite reliability (CR) satisfied the minimum of 0.50 and 0.70 respectively (Fornell and Larcker, 1981; Hair et al., 2011). Discriminant validity was also judged acceptable because the square roots of the AVEs (in the diagonal) are greater than their respective inter-construct correlations as is in Table 2 (Fornell and Larcker, 1981).

\subsection{Structural Model Analysis}

The structural model was assessed through the regression weights, $t$-values, $\mathrm{p}$-values for significance of $\mathrm{t}$-statistics (Chin, 2010; Hair et al., 2011). The results of structural model for testing the research hypotheses are presented in Table 3. 
Table 3. Results of structural model and hypothesis testing

\begin{tabular}{lllllll}
\hline $\begin{array}{l}\text { Hypothesized } \\
\text { relationship }\end{array}$ & $\begin{array}{l}\text { Regression } \\
\text { weight }\end{array}$ & $\begin{array}{l}\text { Standard } \\
\text { Error }\end{array}$ & T-Statistics & p-value & Remarks \\
\hline H1 & APOL -> WTS & 0.0347 & 0.047 & 0.7392 & 0.461 & Not supported \\
H2 & WEC -> WTS & 0.299 & 0.0378 & 7.9153 & $0.000^{* * *}$ & Supported \\
H3 & COMP -> WTS & 0.3236 & 0.0523 & 6.1861 & $0.000^{* * *}$ & Supported \\
H4 & WDI -> WTS & 0.1127 & 0.0483 & 2.3325 & $0.021^{*}$ & Supported \\
H5 & MES -> WTS & 0.1481 & 0.0537 & 2.7588 & $0.006^{* *}$ & Supported \\
\hline
\end{tabular}

Note: ** significant at 0.01, *** significant at 0.001. APOL - apology, WEC - Waiting environment comfort, COMP

- Compensation for waiting, WDI- Waiting delay information, MES - mind-engagement strategies, WTS - waiting time satisfaction

The results in Table 3 show that, four out of five hypotheses were supported by the data. First of all, apart from apology (H1a) all the other organisation time management strategies significantly influenced customer perceived WTS, confirming hypotheses H1b, H1c, H1d and H1e. Specifically, while the relationship between WTS and apology was not significant $(\beta=0.0347, \mathrm{t}=0.739, \mathrm{p}>0.05)$, there was a significantly positive relationship between WTS and the following independent variables $\operatorname{WEC}(\beta=0.299, \mathrm{t}=7.915, \mathrm{p}<0.001), \operatorname{COMP}(\beta=0.323, \mathrm{t}=6.186, \mathrm{p}$ $<0.001)$, WDI $(\beta=0.112, \mathrm{t}=2.332, \mathrm{p}<0.05)$ and $\operatorname{MES}(\beta=0.148, \mathrm{t}=2.758, \mathrm{p}<0.01)$. Moreover, among the significant predictors, compensation made the greatest influence on customer perceived WTS, followed by waiting environment, mind-engagement strategies and delay information. Overall all the independent variables of organisation WTM strategies predicted perceived customer WTS by $45 \%$ (R-square).

\section{Discussion and Implications}

The main purpose of this study was to assess the effect of organisation's WTM strategies on bank customers' WTS in Ghana. Using structural model analysis, the findings indicate that, apart from apology, there was a significantly positive effect of organisation's WTM strategies and bank customers' WTS.

First, this study found that bank customers WTS was not significantly influenced by apology from service providers about the inconveniences caused customers for waiting unduly long. Although previous research has shown that apology may reduce customer dissatisfaction for long PWT (e.g., Bougoure et al., 2015; Lee et al., 2012; Lin et al., 2015; Nadiri, 2016; Sobh, 2014; Tarofder et al., 2016), the findings of this study indicate that, for bank customers in Ghana, apologising for long PWT might not be sufficient to influence their WTS evaluations for a banking service provider. Several reasons may account for this contradictory situation. First, theoretically, there might be latent underlying cultural and situational factors that also significantly influence bank customers' perception of the effectiveness of service providers' apology to customers. In this regard, Maher and Sobh (2014) found that apologies might not have significant effect on waiting satisfaction in the situation of intercultural service encounters involving service employees and customers from different cultures (Sharma et al., 2009). The effectiveness of apology to positively influence customer waiting satisfaction may also depend on the level of severity of anger the customer experiences (Maher and Sobh, 2014). As a result of these situational factors that influence the effective use of apology, Lee et al. (2012) showed that apology with rewards might be more effective in creating WTS than rendering only apology.

This study also found empirical support for the positive effect of compensation on bank customers' WTM. Thus, effective use of compensation could help bank practitioners reduce bankers' waiting time dissatisfaction, confirming past studies (e.g., Antonides et al. 2002; Hill et al. 2000; Kumar et al., 1997; Lin et al., 2015). Moreover, the study's findings on the positive relationship between waiting environment, mind-engagement strategies and delay information comfort and WTS are consistent with many past studies in banking and non-banking contexts (e.g., Antonides et al. 2002; Lee et al., 2012; Lin et al., 2015; Kumar et al., 1997; Kumar and Krishnamurthy, 2008; Hui and Tse, 1996; Taylor, 1994; Bougoure et al., 2015; Lee et al., 2012; Lin et al., 2015; Nadiri, 2016; Sobh, 2014; Tarofder et al., 2016). This implies that the more bank service providers provide comfortable waiting environment, quality information on waiting time, and develop effective mind-engagement fillers, the more bank customers will be positively influenced to be satisfied with waiting time. As has been demonstrated, generally, these findings are consistent with previous studies that organisation PWT fillers could be effectively used to manage customer PWT to 
avoid customer switching and disloyalty behaviours (Abbasi et al., 2013; Bielen et al., 2007; Palawatta, 2015; Tarofder et al., 2016).

\subsection{Theoretical Implications}

First, theoretically, the findings imply that the use of WTM strategies by banking service providers might result in different effect on customer perception of waiting time, customers' evaluation and satisfaction of waiting time within a specific banking industry context. While the application of a particular WTM strategy may be more effective in a given customer situation and in a particular banking service context, it might be less effective in a different context. In this regard, this study did not find support for the positive effect of apology on bank customers' WTS in Ghana while previous research had empirical support between apology and WTS (e.g., Nadiri, 2016; Sobh, 2014; Tarofder et al., 2016). Even within the significant predictors of WTS found in this study, the greatest was compensation, followed by waiting environment, mind-engagement strategies and provision of information on delay. This result may be different. Similarly, Lee et al. (2012) found that, even within a particular range of waiting time fillers, music made a stronger impact on customers' waiting time evaluation than news, information on waiting time and entertainment. Therefore, research should attempt to highlight context-specific WTM strategies and provide research information on differences in WTM across different service contexts, especially in multi-context studies.

Second, theoretically, the findings add to empirical studies in WTM strategies and WTS and perceived waiting time in developing countries which has received little empirical research (e.g., Abbasi et al., 2013). This study, therefore, increases our knowledge of WTM and provides support for previous studies that organisational effort and strategies targeted at filling consumers PWT could significantly influence consumer WTS. This contributes to theoretical support for effective management of customer PWT and WTS. It means that bank customers PWT can be managed by financial institutions to achieve sustainable business growth (Bielen et al., 2007; Bougoure et al., 2015; Gohary et al. 2016; Lee et al., 2012; McQyuilken, 2017; Nadiri, 2016; Palawatta, 2015; Tarofder et al., 2016).

\subsection{Managerial CONTRIBUTION}

First, since this study showed that apology may not be sufficient to positively influence bank customers' WTS, it implies that banking service providers in general and Ghana in particular should not rely solely on apology as a stand-alone WTM strategy. While apology for delaying customers might be a last resort, banking practitioners should adopt more holistic, integrated form of WTM strategy which effectively combines rewards, waiting time fillers, waiting environment comfort cues together with apology. Such an integrated WTM strategy could make up for the inadequacies of focusing on only the use of apology for achieving customers WTS as suggested in previous studies (Lee et al., 2012).

Second, Management of financial service firms should avoid causing unreasonable service delays and long waiting time for bank customers. Bank managers should provide timely information on service delays and waiting times in order to reduce waiting uncertainties among bank customers. They should also provide effective explanations for customer waiting or service delays. Here bank practitioners should harness the use of internet and other electronic platforms to deliver information on delays to customers quickly and promptly either before they come to banking halls or online banking service environment or during waiting for service completion depending on type of banking services customers are waiting to receive.

Third, bank managers should develop appropriate compensation for customers who patiently wait when they encounter service delays and inconveniences. As has been shown in this study and those of others, these compensation or rewards for waiting have the capacity to shorten customers' perceived waiting period and their satisfaction of the waiting time for service (Lee et al., 2012).

Fourth, bank managers should provide comfortable banking environment that reduces perceived waiting time in order to achieve high customer WTS. In particular, waiting environment should be neat, not congested, welcoming, refreshing, pleasant, attractive with appropriate temperature and seating for relaxation.

Fifth, bank managers should provide tactful fillers to engage the minds of customers while they wait for service to be completed. Examples of such fillers are appropriate music, menu information, newspapers, TV shows, movies, among others. The use of waiting time fillers should be strategically purposeful. According to Lee et al. (2012, p. 201),

..the peak-and-end rule assumes that people evaluate their experiences on the basis of both the most extreme and the final episodes. A happy ending of the waiting time, for example, a very nice musical theme, may lead to even better wait evaluations, even if it takes a few extra seconds to listen to this happy end. Also, the end of the waiting time itself may cause a happy ending, although alternatively one might consider this the beginning of a new episode 
(service time).

Sixth, bank managers should also train staff to improve upon speed of service delivery and effective communication in handling customer complaints for unacceptable waiting time. Front-line banking staff should be well educated and trained to understand customer reactions to waiting time and how to overcome the emotional stress that can be experienced from encounters with angry customers. Thus, consistent periodic staff training in customer complaint and waiting time management is necessary for improving the skills, knowledge and attitude of bank staff in achieve service recovery and customer satisfaction.

Seventh, bank managers should also endeavour to adopt the use of modern information and communication technology to re-engineer and manager their business process. This could result in the removal of time consuming business processes and the use of information and self-service technologies to reduce the duplication of human effort in service delivery. It could also help ensure that business processes are relatively short, easy and simple to follow by customers. The key thrust for business process re-engineering and management is banking innovations in all areas necessary such as marketing, finance, accounting, and information technology. With the apt to innovate, banking institutions will be well-positioned to capture bank customers' changing taste, preferences and wants for banking services and will be able to develop innovative bank marketing strategic solutions to manage them.

\section{Limitations and Conclusion}

This study examined the effect of organisation's WTM strategies on bank customers WTS in Ghana banking industry. It draws on existing literature from psychology and marketing to develop a conceptual framework for the study. Using data from a survey of 480 bank customers in Ghana, the results show that four of the proposed OWTM strategies such as perceived compensation, waiting environment, quality of delay information, and customer mind-engagement strategies significantly influenced bank customers' WTS. This study provides empirical knowledge for financial service managers in developing effective strategies for managing PWT.

It is recommended that future research should broaden the scope of the effect of bank institutions' WTM on other bank customer behaviour such as loyalty and recommendation of service provider in different developing countries. Future research could also perform multi-group analysis to high differences in the effect of WTM strategies on WTS among different respondents' groups based on gender, age, income, education and bank service type. While this study is limited in terms of generalizability of the findings in developing countries, it provides avenues for further research in understanding critical determinants of customer satisfaction with PWT in financial markets.

\section{References}

Abbasi, H., Rahimi, F., \& Senobari, M. (2013). The Impact of Waiting Time on Customer Satisfaction and Loyalty in the State and Private Banks in Tehran. World of Sciences Journal, 1(16), 161-174.

Antonides, G., Verhoef, P. C., \& Van Aalst, M. (2000). Consumer Perception and Evaluation of Waiting Time. Journal of Consumer Psychology, 12(3), 193-202. https://doi.org/10.1207/S15327663JCP1203_02

Bae, G., \& Kim, D. Y. (2014). The effects of offering menu information on perceived waiting time. Journal of Hospitality Marketing and Management, 23(7), 746-767. https://doi.org/10.1080/19368623.2014.879547

Bielen, F. \& Demoulin, N. (2007). Waiting time influence on the satisfaction-loyalty relationship in services. Managing Service Quality, 17(2), 174-193. https://doi.org/10.1108/09604520710735182

Bougoure, U. S., Russell-Bennett, R., Fazal-E-Hasan, S., \& Mortimer, G. (2016). The impact of service failure on brand credibility. Journal of Retailing and Consumer Services, 31, 62-71. https://doi.org/10.1016/j.jretconser.2016.03.006

Broberg, P., Umans, T., \& Gerlofstig, C. (2013). Balance between auditing and marketing: An explorative study. Journal of International Accounting, Auditing and Taxation, 22(1), 57-70. https://doi.org/10.1016/j.intaccaudtax.2013.02.001

Cameron, M.A., Baker, J., Peterson, M., \& Braunsberger, K. (2003). The effects of music, wait-length evaluation, and mood on a low-cost wait experience. Journal of Business Research, 53, 421-430. https://doi.org/10.1016/S0148-2963(01)00244-2

Chin, W. (2010). How to write up and report PLS analyses. In: EspositoVinzi V, Chin W.W, Henseler J, Wang H (eds) Handbook of partial least squares: concepts, methods and applications. Springer Heidelberg, 655 - 690 . https://doi.org/10.1007/978-3-540-32827-8_29

Collier, P. M. (2015). Accounting for managers: Interpreting accounting information for decision making. John 
Wiley and Sons.

Danaher, P. J., \& Haddrell, V. (1996). A comparison of question scales used for measuring customer satisfaction. International Journal of Service Industry Management, 7(4), 4-26. https://doi.org/10.1108/09564239610129922

Fornell, C., \& Larcker, D. F. (1981). Evaluating structural equation models with unobservable variables and measurement error. Journal of Marketing Research, 18, 39-50. https://doi.org/10.2307/3151312

Gohary, A., Hamzelu, B., Pourazizi, L., \& Hanzaee, K. H. (2016). Understanding effects of co-creation on cognitive, affective and behavioral evaluations in service recovery: An ethnocultural analysis. Journal of Retailing and Consumer Services, 31, 182-198. https://doi.org/10.1016/j.jretconser.2016.03.016

Hair, J. F., Black, W. C., Babin, B. J., \& Anderson, R. E. (2010). Multivariate Data Analysis. Englewood Cliffs, NJ: Prentice Hall.

Hair, J., Ringle C. M., \& Sarstedt M. (2011). PLS-SEM: Indeed a Silver Bullet. Journal of Marketing Theory and Practice, 19(2), 139-151. https://doi.org/10.2753/MTP1069-6679190202

Hill V.A., Hays M.J., Naveh E. (2000). A model for optimal delivery time guarantees. Journal of Service Research 2(5), 254-264. https://doi.org/10.1177/109467050023003

Houston, M.B., Bettencourt, L.A., Wenger, S. (1998). The relationship between waiting in a service queue and evaluations of service quality: a field theory perspective. Psychology and Marketing, 15(8), 735-753. https://doi.org/10.1002/(SICI)1520-6793(199812)15:8<735::AID-MAR2>3.0.CO;2-9

Hui M.K., Tse D.K., (1996). What to tell consumers in waits of different lengths: an integrative model of service evaluation. Journal of Marketing, 60(2), 81-90. https://doi.org/10.2307/1251932

Hui, M.K., Dube, L., \& Chebat, J.C. (1997). The impact of music on consumers' reaction to waiting for services. Journal of Retailing, 73(1), 87-104. https://doi.org/10.1016/S0022-4359(97)90016-6

Hwang, J., \& Lambert, C. U. (2005). 'Customers' identification of acceptable waiting times in a muti-stage restaurant system. Journal of Foodservice Business Research, 8(1), 3-16. https://doi.org/10.1300/J369v08n01_02

Jaakkola, E., \& Alexander, M. (2014). The Role of Customer Engagement Behavior in Value Co-Creation A Service System Perspective. Journal of Service Research, 1-15.

Katz, K.L., Larson B.M., \& Larson, R.C. (1991). Prescription for the waiting-in-line blues: entertain, enlighten, and engage. Sloan Management Review, 32(2), 44-53.

Kotler, P. \& Armstrong, A. (2014). Principles of Marketing. Global Edition, 15th ed., Pearson.

Kotler, P. \& Keller, K. (2016). Marketing Management (Global Edition, 15/e), Hardcover, Prentice Hall.

Kumar, P. \& Krishnamurthy P. (2008). The impact of service-time uncertainty and anticipated congestion on customers' waiting-time decisions. Journal of Service Research, 10(3), 282-292. https://doi.org/10.1177/1094670507313543

Kumar P., Kalwani M.U., \& Dada M. (1997). The impact of waiting time guarantee on customers' waiting experiences. Marketing Science, 16(4), 295-314. https://doi.org/10.1287/mksc.16.4.295

Lee, Y., Chen, A. N., \& Ilie, V. (2012). Can Online Wait Be Managed? The Effect of Filler Interfaces and Presentation Modes on Perceived Waiting Time Online. MIS Quarterly, 36(2), 365-394.

Lerclec, F., Schmidt, B., \& Dubé, I. (1995). Waiting Time and Decision Making: Is time like money? Journal of Consumer Research, 22(1), 110-119. https://doi.org/10.1086/209439

Lin, Y. T., Xia, K. N., \& Bei, L. T. (2015). Customer's perceived value of waiting time for service events. Journal of Consumer Behaviour, 14(1), 28-40. https://doi.org/10.1002/cb.1498

Maher A. A. \& Sobh R. (2014). The role of collective angst during and after a service failure. Journal of Services Marketing, 28(3), 223-232. https://doi.org/10.1108/JSM-10-2012-0203

Maister, D. H. (1985). The Psychology of Waiting Lines. In J. A. Czepiel, M. R. Solomon and C. F. Surprenant (Eds.) The Service Encounter: Managing employee/customer interaction in service businesses (pp. 113- 123). Lexington, MA: Lexington Books.

Mostafa, R., R. Lages, C., \& Sääksjärvi, M. (2014). The CURE scale: a multidimensional measure of service recovery strategy. Journal of Services Marketing, 28(4), 300-310. https://doi.org/10.1108/JSM-09-2012-0166 
Nadiri, H. (2016). Diagnosing the impact of retail bank customers' perceived justice on their service recovery satisfaction and postpurchase behaviours: an empirical study infinancial centre of middle east. Ekonomska istraživanja, 29(1), 193-216.

Opute, A. P., \& Madichie, N. O. (2016). An interrogation of accounting-marketing interface in UK financial services organisations: Mixing cats with dogs? Australasian Marketing Journal (AMJ), 24(3), 214-225. https://doi.org/10.1016/j.ausmj.2016.06.001

Palawatta, T. M. B. (2015). Waiting Times and Defining Customer Satisfaction. Vidyodaya Journal of Management, $1(1), 15-24$.

Pruyn, A. \& Smidts, A. (1993). Customers' Evaluations of Queues: Three Exploratory Studies, in European Advances in Consumer Research Volume 1, eds. W. Fred Van Raaij and Gary J. Bamossy, Provo, UT: Association for Consumer Research, 371-382.

Ringle, C. M., Wende, S., \& Becker, J. (2015). SmartPLS 3.1.7. Bönningstedt: SmartPLS GmbH. http://www.smartpls.de

Sarens, G., Everaert, P., Verplancke, F., \& Beelde, I. (2015). Diversification of External Accountants Serving Small and Medium - sized Enterprises: Evidence from Belgium. Australian Accounting Review, 25(2), 155-174. https://doi.org/10.1111/auar.12078

Smidts, A. \& Pruyn, A. (1994). How waiting affects customer satisfaction with the service: the role of subjective variables. Management of Services: a multidisciplinary approach, (3rd conference), 677-696.

Tarofder, A. K., Nikhashemi, S. R., Azam, S. F., Selvantharan, P., \& Haque, A. (2016). The mediating influence of service failure explanation on customer repurchase intention through customers satisfaction. International Journal of Quality and Service Sciences, 8(4), 516-535. https://doi.org/10.1108/IJQSS-04-2015-0044

Taylor, S. (1994). Waiting for service: The relationship between delays and evaluations of service. Journal of Marketing, 58(2), 56-69. https://doi.org/10.2307/1252269

Vargo, S. L. \& Lusch R. F. (2014). Inversions of service-dominant logic. Marketing Theory, 14(3), 239-248. https://doi.org/10.1177/1470593114534339

Voorhees, C.M., Baker J., Bourdeau B.L., Brocato E.D., \& Cronin J.J., Jr. (2009). It depends: moderating the relationships among perceived waiting time, anger, and regret. Journal of Service Research, 12(2), 138-155. https://doi.org/10.1177/1094670509336744

Wirtz J, \& Mattila, A.S. (2004). Consumer responses to compensation speed of recovery and apology after a service failure. International Journal of Service Industry Management, 15(2), 150-166. https://doi.org/10.1108/09564230410532484 